\title{
The Need for a Federal Anti-SLAPP Law in Today's Digital Media Climate
}

\author{
Lauren Bergelson*
}

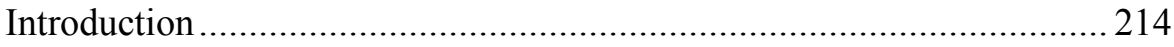

I. Background on the Legal Context Presiding over the Digital

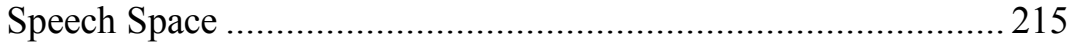

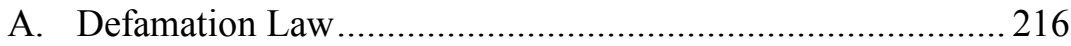

B. Privacy Law ..................................................................... 217

C. The Blurry Line Between the Two....................................... 220

D. Media Neutrality ................................................................ 221

II. The Problem of Third-Party Litigation Funding in the Digital

Speech Space ........................................................................ 223

A. Billionaires Finance Litigation Targeting Negative

Reporting

1. Gawker's Expensive Loss in the Bollea v. Gawker Invasion

of Privacy Lawsuit, Secretly Financed by Peter Thiel...... 223

2. The Mother Jones's Defamation Suit and Frank VanderSloot's Fund for Future Lawsuits ........................ 226

B. The Chilling Effect of Possible Billionaire-Backed Lawsuits 228

III. A Federal Anti-SLAPP Law as a Possible Solution...................... 230

A. Anti-SLAPP Law Origins..................................................... 231

B. Contemporary Anti-SLAPP Law Context ............................ 231

C. What Should a Federal Anti-SLAPP Law Look Like?........... 233

1. The SPEAK FREE Act of 2015 .................................... 233

2. Important Features to Include in Future Bills.................. 234

a. A Broad SLAPP Definition with Specific Exceptions.

b. A Pleading Standard that Avoids Both Vagueness

Concerns and a 7th Amendment Conflict .................. 236

c. A Removal Provision that Includes Explicit

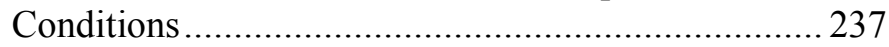

d. An Enumerated Commerce Clause Hook ................. 239

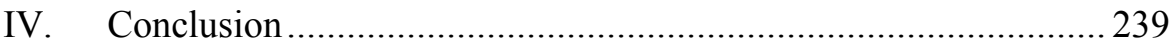




\section{INTRODUCTION}

The Internet can be a major catalyst for the potential damage of defamatory statements and privacy revelations. The reach, permanence, and accessibility of Internet-posted information amplify the potential for harm and offense. ${ }^{1}$ Likewise, technological changes, shifting journalistic trends, and the reality that anyone in the Internet era is a "content creator wielding immense power to destroy another person's privacy" push the boundaries between press freedom and personal privacy rights. ${ }^{2}$ Similarly, the availability of new digital platforms allows individuals the power to shape their images in novel ways. Some scholars suggest that this power allows for a "growing 'claims consciousness' around personal image." 3 As opportunities for shaping one's image have grown in the digital age, so have opportunities for damaging the reputation of oneself or another. ${ }^{4}$ Relatedly, such developments have prompted greater public acceptance of bringing lawsuits. ${ }^{5}$

Following the publication of a story involving two women accusing Donald Trump of inappropriately touching them years ago, Marc E. Kasowitz, Donald Trump's lawyer, demanded that The New York Times retract the story, or face legal action. ${ }^{6}$ Fortunately, such demands do not appear to intimidate The Times. In fact, the newspaper invited the threatened action, standing by the legality of its publication and welcoming "the opportunity to have a court set [Donald Trump] straight."

Not all presses, however, enjoy The Times's deep pockets, legal expertise, or history of success in libel cases. ${ }^{8}$ Though the threat of expensive litigation draining editorial resources is not new, ${ }^{9}$ Peter Thiel's vengeful involvement in the Gawker suit and Frank VanderSloot's alleged creation of a litigation fund to finance lawsuits against a particular type of media constitute dangerous examples of billionaires

* J.D. Candidate, Columbia Law School, Class of 2019; B.A., Cornell University, Class of 2016; 2018-2019 Executive Submissions Editor and Articles Editor of the Columbia Journal of Law \& the Arts. The author would like to thank Professor Jeremy Kessler for his invaluable insights and advice, the staff of the Journal for their thoughtful review, and her family for their patience and support.

1. Clay Calvert, Panel III: The Future of the Press and Privacy, 19 COMM. L. \& POL'Y 119, 122 (2014)

2. Id. at 119 .

3. Samantha Barbas, Laws of Image: Privacy and Publicity in America 200 (2015).

4. Emma Altheide, Arbitration for the "Afflicted" - the Viability of Arbitrating Defamation and Libel Claims Considering Ipso's Pilot Program, 2017 J. DisP. Resol. 165, 170 (2017).

5. Id.

6. Alan Rappeport, Donald Trump Threatens To Sue The Times over Article on Unwanted Advances, N.Y. TIMES (Oct. 13, 2016), https://perma.cc/W9UM-UND2.

7. Id.

8. THE NEW YORK TIMES has not lost a libel suit in the United States since at least the early 1960s. See Liz Spayd, A Rare Libel Suit Against The Times, N.Y. TIMES (May 10, 2017), https://perma.cc/PRT69NRT.

9. See Green v. Alton Tel. Printing Co., 438 N.E.2d 203 (Ill. App. Ct. 1982).

(C) 2019 Bergelson. This is an open access article distributed under the terms of the Creative Commons Attribution License, which permits unrestricted use, distribution, and reproduction, provided the original author and source are credited. 
sponsoring lawsuits against media they dislike. ${ }^{10}$ Today's media climate, characterized by increased access, new journalistic styles, and a growing "claims consciousness," coupled with the possibility of wealthy third-party litigation financiers utilizing the judicial system to target and weaken media outlets, warrants strong protections in the form of a federal anti-SLAPP law.

This Note lays out the judicial protections granted to the traditional press and identifies new threats to non-traditional presses through the rise of third-party litigation financing for lawsuits targeting negative reporting. Part I distinguishes between libel and privacy lawsuits, explaining why one approach - particularly in the digital age - can be more fruitful for plaintiffs. Part I also draws from recent Supreme Court precedent to contextualize current attitudes regarding speech and privacy. Part II analyzes two recent new media cases with troubling results: specifically, million-dollar costs at best, and bankruptcy at worst. While ample protections exist for the traditional press, in light of these lawsuits, it is worth considering what more could and should be done to protect media outlets, especially the non-traditional presses. Part II also examines the chilling effect of potential billionaire-backed lawsuits. Because of threats from third-party litigation financiers and because judicial protections are intended for traditional presses, new publishers are left in a precarious position; Part III advocates for a federal anti-SLAPP law as a potential solution.

\section{BACKGROUND ON THE LEGAL CONTEXT PRESIDING OVER THE DIGITAL SPEECH SPACE}

This section briefly explains the development of defamation and privacy law. It distinguishes between the two types of lawsuits, clarifying why one approach, especially in the digital age, can be more productive for plaintiffs. This section also contextualizes the Supreme Court's recent views on different types of speech. In particular, it draws attention to the Court's reluctance to make rules differentiating between types of media, as well as its recognition of digital media as an important new space for speech. Together, these subsections reveal additional factors affecting contemporary media outlets in the digital space.

10. See Luisa Kroll \& Kerry A. Dolan, Forbes 400: The Definitive Ranking of the Wealthiest Americans, \#328 Peter Thiel, FORBES (Oct. 3, 2018), https://perma.cc/GP79-MPAV; id. at \#172 Frank VanderSloot, https://perma.cc/53CZ-KDJE; Matt Drange, Peter Thiel's War on Gawker: A Timeline, FORBES (June 21, 2016); VanderSloot Starts Fund To Defend Conservatives Against Defamation, IDAHO ST. J. (Oct. 8, 2015), https://perma.cc/Z9KS-7TFM. 


\section{A. Defamation LaW}

In 1964, the Supreme Court decided New York Times Co. v. Sullivan, arguably the most significant libe $1^{11}$ case in contemporary American history. ${ }^{12}$ Following the publication of an advertisement titled "Heed Their Rising Voices," which called attention to the "wave of terror" facing Southern African-American students engaging in non-violent demonstrations and criticized Montgomery's brutal response to the protests, L.B. Sullivan, one of the three elected Commissioners of the City of Montgomery, sued The New York Times and four African-American clergymen for libel. ${ }^{13}$ Under Alabama law at the time, Sullivan was not required to prove that he had been harmed. The only defense available to The Times was the truthfulness of the advertisement. Because the advertisement contained factual errors, intent was presumed. ${ }^{14}$ A local jury awarded Sullivan $\$ 500,000$, and the Supreme Court of Alabama affirmed. ${ }^{15}$

The Supreme Court of the United States reversed, holding that the Alabama courts had failed to provide the First Amendment protections required by the First and Fourteenth Amendments. ${ }^{16}$ The Court established the landmark "actual malice" standard, integral to proving intent in libel actions brought by a public official against critics of his or her official conduct. This standard requires public officials to prove that the publisher knew the statement was false, or that the publisher had acted with reckless disregard to the statement's truth or falsity. ${ }^{17}$ In this way, the standard focuses on the subjective state of mind of journalists rather than on some established standard of professional responsibility. The same standard also applies to cases concerning defamatory criticism of public figures. ${ }^{18}$

Considered "against the backdrop of a profound national commitment to the principle that debate on public issues should be uninhibited, robust, and wideopen," 19 New York Times Co. v. Sullivan set a crucial precedent for American defamation law. Justice Brennan emphasized the "breathing space" for error necessary to prevent self-censorship. ${ }^{20}$ This "breathing space" differentiates American libel law from its British counterpart. Under British law, any mistake justifies a judgment for the plaintiff if the statement materially injures his or her

11. Libel is one type of defamation. While defamation encompasses false claims of fact about a person, libel refers to such claims that take written or permanent form. Slander, on the other hand, refers to such claims made through verbal statements or gestures. See Defamation FAQs, MEdia L. ReSOuRCE CTR., https://perma.cc/8BG9-ZBRR (last visited Nov. 10, 2018).

12. N.Y. Times Co. v. Sullivan, 376 U.S. 254 (1964).

13. Id. at 256 .

14. Anna Stolley Persky, 50 Years After New York Times v. Sullivan, Do Courts Still Value Journalists' Watchdog Role?, A.B.A. J. (Mar. 2014), https://perma.cc/2854-UFVJ.

15. Sullivan, 376 U.S. at 256 .

16. Id. at 254 .

17. Id. at $279-80$.

18. Curtis Pub. Co. v. Butts, 388 U.S. 130, 164 (1967) (Warren, C.J., concurring).

19. Sullivan, 376 U.S. at 721 .

20. Id. at 271-72 (quoting N.A.A.C.P. v. Button, 371 U.S. 415, 433 (1963)); id. at 279. 
reputation. ${ }^{21}$ British law requires newspapers to prove that a challenged statement is true, which results in almost universal losses for newspapers that go to court to defend a libel suit. ${ }^{22}$ Under Sullivan, the Supreme Court shifted the burden of proof to public official plaintiffs pursuing libel cases. In doing so, the Court enlarged the scope of First Amendment protection for journalists.

Rather than granting absolute immunity for any speech relating to an individual's official conduct, the Court instead allowed for liability for speech involving knowing or reckless falsehood, thereby balancing the interests of upholding free expression and protecting reputation. ${ }^{23}$ Anthony Lewis, a current columnist for The New York Times and the reporter that covered New York Times Co. v. Sullivan, underscores the great weight that reputation carries in the American value system. ${ }^{24}$ In particular, Lewis notes that people previously responded to libel and slander with duel challenges. ${ }^{25}$ The everlasting significance of reputation appears relevant today. One could argue that expensive lawsuits function as the modern-day equivalent of such challenges.

In Gertz v. Robert Welch, Inc., the Supreme Court determined the constitutionally permissible standard for intent in libel actions brought by private individuals. ${ }^{26}$ The Court held that private individuals deserve more protection from defamatory accusations than do public officials and public figures, so the "actual malice" standard does not apply in their cases. The Court left the decision as to the proper standard to the states, with one caveat: they may not impose liability without fault. ${ }^{27}$ The Court emphasized the equitable nature of this decision as it "recognizes the strength of the legitimate state interest in compensating private individuals for wrongful injury to reputation, yet shields the press and broadcast media from the rigors of strict liability for defamation." 28 In most states, private plaintiffs must only show the defendant's negligence. ${ }^{29}$ While New York Times Co. v. Sullivan eliminated strict liability from defamation cases involving public officials and public figures, Gertz eliminated liability without fault from defamation cases involving private individuals. ${ }^{30}$

\section{B. Privacy Law}

While both the Supreme Court and Congress have described privacy as a fundamental right for certain purposes, no general constitutional or statutory right to

\footnotetext{
21. Anthony Lewis, Make No Law: The Sullivan CaSe AND the FiRst Amendment 157 (1991).

22. Id.

Id. at 154 .

Id.

Id.

Gertz v. Robert Welch, Inc., 418 U.S. 323, 325 (1974).

Id. at $347-48$.

Id.

Defamation FAQs, MEDIA L. RESOURCE CTR., https://perma.cc/YMF4-797P.

30. 1 John J. Kircher \& Christine M. Wiseman, Punitive Damages: LaW and Practice $\S$ 13:10 (2d ed. 2018).
} 
privacy exists under federal or state law. ${ }^{31}$ Rather, certain specific privacy rights or interests exist in defined areas. ${ }^{32}$ Further, the Supreme Court has stated that protection of an individual's general right to privacy falls largely under the purview of the states. ${ }^{33}$ Nearly every state recognizes the right to privacy to some extent, either by statute or by common law, but the way in which each state defines the legal elements of a claim and the corresponding scope of protection vary. ${ }^{34}$

Notably, the first major theoretical discussion of the right to privacy was a response to concerns about journalistic invasions of individual privacy. Samuel Warren and Louis Brandeis began the conversation in their 1890 Harvard Law Review article titled The Right to Privacy. ${ }^{35}$ Concerned with press intrusion into personal and family life, as well as the prevalence of "yellow journalism," Warren and Brandeis argued that the common law should be read to protect the right to privacy. ${ }^{36}$ By analyzing a series of prior decisions that granted relief on the bases of defamation, property, breach of confidence, and implied contract, they concluded that while these decisions did not sufficiently protect against invasions of privacy, they were based on a broader principle of the right to privacy that deserved its own recognition. ${ }^{37}$

While Warren and Brandeis popularized privacy in American law, William Prosser was its "chief architect." 38 Prosser clarified the concept of the "right to privacy" by categorizing it into four related, but discrete privacy torts. ${ }^{39}$ They include: intrusion upon seclusion; public disclosure of private facts (also known as publicity given to private life); false light publicity; and appropriation of name or likeness. ${ }^{40}$ As the chief reporter for the Second Restatement of Torts, Prosser codified his conception of privacy law within it. ${ }^{41}$ Today the Restatement serves as the leading authority on the subject matter to which most courts refer. ${ }^{42}$

Intrusion upon seclusion and public disclosure of private facts constitute the privacy torts most central to this Note. Under the Second Restatement of Torts, intrusion upon seclusion provides liability for one who "intentionally intrudes, physically or otherwise, upon the solitude or seclusion of another or his private affairs or concerns" in a manner that would be "highly offensive to a reasonable

31. Gerald B. Cope, Jr., Toward a Right of Privacy as a Matter of State Constitutional Law, 5 FLA. ST. U. L. Rev. 631, 636 (citing Griswold v. Connecticut, 381 U.S. 479, 485 (1965) and the Privacy Act of 1974, Pub. L. No. 93-579 § 2(a)(4), 88 Stat. 1896).

32. Id.

33. Katz v. United States, 389 U.S. 347, 349-51 (1967).

34. Practical Law Intellectual Property \& Technology, Right of Privacy: Overview, Practical Law Practice Note Overview w-009-4039, WESTLAW (UK) (2018).

35. Samuel D. Warren \& Louis Brandeis, The Right to Privacy, 4 HARV. L. REV. 193 (1890).

36. Id. at 213 .

37. William Prosser, Privacy, 48 CALIF. L. REV. 383, 384 (1960).

38. Neil M. Richards \& David K. Solove, Prosser's Privacy Law: A Mixed Legacy, 98 CALIF. L. REV. 1887, 1887-88 (2010).

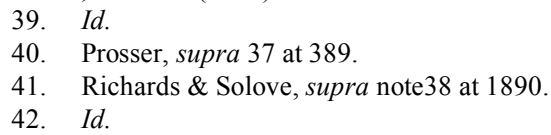


person." 43 The Comments to the Restatement clarify that intrusion upon seclusion does not depend on any publicity given to the person whose interest is invaded, but deals only with an interference with one's solitude or seclusion. ${ }^{44}$

Public disclosure of private facts provides liability for one who "gives publicity to a matter concerning the private life of another ... if the matter publicized is of a kind that (a) would be highly offensive to a reasonable person, and (b) is not of a legitimate concern to the public." 45 The second prong is often referred to as newsworthiness. Unlike intrusion upon seclusion, which concerns the way in which information is obtained, public disclosure of private facts concerns the nature of the information and the manner in which it is divulged.

Newsworthiness is integral to invasion of privacy lawsuits and proves especially relevant here, as it serves as a defense to legal causes of action for public disclosure of private facts. In 1975, the San Francisco Chronicle commended Oliver Sipple's bravery after he foiled an assassination attempt on President Gerald Ford. ${ }^{46}$ In the process, the newspaper divulged that Sipple was gay, and the revelation permeated the national news. ${ }^{47}$ Sipple sued the newspaper for invasion of privacy, claiming publicity given to private life. ${ }^{48}$ The Superior Court in San Francisco dismissed the case because the record failed to state a triable issue of fact and the decision was affirmed on appeal. ${ }^{49}$

Though Sipple's sexual orientation was not yet known in his hometown of Detroit, the Court determined that information regarding his sexual orientation was not private since he was well-known in the San Francisco gay community ${ }^{50}$ Moreover, it clarified that involuntary fame is not a defense, so even though Sipple may not have intended to enter the limelight when he chose to save the President, through his conduct he became a legitimate subject of public interest. ${ }^{51}$ Given the circumstances, the Court determined that the information disclosed regarding Sipple's background and sexual orientation was newsworthy. ${ }^{52}$

Since New York Times Co. v. Sullivan established the "actual malice" standard, plaintiffs have struggled to win libel cases. ${ }^{53}$ However, unlike in defamation cases, where the plaintiff must prove falsity or actual malice, plaintiffs in invasion of privacy cases do not have to meet such onerous burdens of proof. For example, in publicity given to private life claims, like that made in Sipple, plaintiffs must prove only that the publicized matter is of a kind that would be highly offensive to a

43. RESTATEMENT (SECOND) OF TORTS $\S 652 \mathrm{~B}$ (1977).

44. RESTATEMENT (SECOND) OF TORTS $§ 652 \mathrm{~B}$, cmt. a (1977).

45. RESTATEMENT (SECOND) OF TORTS § 652D (1977).

46. Sipple v. Chronicle Publishing Co., 154 Cal. App. 3d 1040, 1043-44 (Cal. Ct. App. 1984).

47. Id.

48. Id. at 1044 .

49. Id. at 1050 .

50. Id. at 1049 .

51. Id. at $1049-50$.

52. Id. at $1048-50$.

53. David Boies, The Chilling Effect of Libel Defamation Costs: The Problem and Possible Solution, 39 ST. LOUIS U. L.J. 1207, 1209 (1995). 
reasonable person, and that it is not newsworthy. ${ }^{54}$ George Freeman, the Executive Director of the Media Law Resource Center, explained that "we have always felt that privacy was a more fruitful ground for plaintiffs to sow," especially since "the whole celebrity culture gives rise to more of these issues." 55 Libel and privacy's different requirements lend support to the idea that invasion of privacy claims can be more effective for plaintiffs.

\section{The Blurry Line Between the Two}

Though courts have found in favor of the press on the issue of newsworthiness, these decisions are often fact-specific in nature and cannot be relied on too heavily by publishers today. Like the court in Sipple, the Supreme Court found in favor of the press on the issue of newsworthiness in its 2001 Bartnicki v. Vopper decision. That is, the Court found no liability when a radio commentator broadcast a telephone conversation covertly recorded by a third party. ${ }^{56}$ The conversation, involving a teachers' union negotiator's discussion of the possibility of using violence to influence a school board, was deemed sufficiently newsworthy to outweigh the callers' privacy. ${ }^{57}$ In fact, the Court clarified that "privacy concerns give way when balanced against the interest in publishing matters of public importance."

However, the Court construed the issue narrowly, deciding only the degree of protection the First Amendment provides to speech that discloses the contents of a communication intercepted illegally. ${ }^{59}$ Writing for the Court, Justice Stevens explained the narrow construction, asserting that it aligns with the Court's reluctance to demarcate firmly between the First Amendment and privacy law and "answer categorically whether truthful publication may ever be punished consistent with the First Amendment." 60 Stevens continued: "We continue to believe that the sensitivity and significance of the interests presented in clashes between [the] First Amendment and privacy rights counsel relying on limited principles that sweep no more broadly than the appropriate context of the instant case." ${ }^{\prime \prime 1}$ As follows, Bartnicki reveals the fact-specific nature of the analysis required when considering the newsworthiness of the information in relation to a subject's privacy interests. Moreover, the case highlights the blurry divide between unacceptable invasions of privacy and acceptable speech on matters of public concern. Illustrating the degree of uncertainty in this area, Bartnicki should not be viewed by publishers as an assurance of a court's likelihood of finding newsworthiness in the future.

Further complicating this area is the fact that publishers may have reason to be wary of courts' newsworthiness analysis. According to Amy Gajda, law professor

54. RESTATEMENT (SECOND) OF TORTS $§ 652$ D (1977).

55. Jeffrey Toobin, Gawker's Demise and the Trump-Era Threat to the First Amendment, NEW YORKER (Dec. 19, 2016), https://perma.cc/4RKE-786J.

56. Bartnicki v. Vopper, 532 U.S. 514 (2001).

57. Id. at 534-35.

58. Id. at 534 .

59. Id. at 517 .

60. Id. at 529 .

61. Id. (citing Florida Star v. B.J.F., 491 U.S. 524, 532-33 (1989)). 
at Tulane University Law School and author of The First Amendment Bubble: How Privacy and the Paparazzi Threaten a Free Press, in the past, courts tended to defer to the press regarding what was newsworthy. ${ }^{62}$ But today, the courts' implicit trust in the media demonstrated by previous rulings might not extend to website operators of non-traditional media. ${ }^{63}$ Gajda argues that courts now view newsworthiness "in a dangerously subjective way to show that today's Internet-based media sometimes doesn't have the same ethics constraints as more mainstream media, leading to a more judgmental bench eager to question news value." ${ }^{\prime 64}$ Despite its ultimate propress holding, Bartnicki's narrow construction sheds light on Gajda's argument and warrants caution in the digital age.

\section{Media Neutrality}

In addition to the blurry line between defamation and privacy law, the Court has been reluctant to carve out certain types of media for special treatment. As a result, this makes it difficult to predict how the Court will respond to the growing threats to non-traditional presses. Citizens United v. Federal Election Commission in particular provides an important example of the Supreme Court's unwillingness to make rules distinguishing between different types of media. In Citizens United, the Court not only held that corporations have the same First Amendment rights as natural persons, but it also clarified that the institutional press does not enjoy any constitutional privilege in addition to that which is extended to other speakers. ${ }^{65}$

Rodney A. Smolla, First Amendment scholar and current dean of Widener University Delaware Law School, asserts that the highly volatile nature of modern media is partly responsible for this reluctance. ${ }^{66}$ Citing Citizens United, Smolla argues that "rapid changes in technology, business models for information and communications companies, and changes in cultural habit" contribute to this volatility. ${ }^{67}$ Smolla highlights the Court's acknowledgement of how technological developments shape and characterize today's speech: "Our Nation's speech dynamic is changing, and informative voices should not have to circumvent restrictions to exercise their First Amendment rights. Speakers have become adept at presenting citizens with sound bites, talking points, and scripted messages that dominate the 24hour news cycle." 68

The Court's opinion in Citizens United acknowledges the role of corporations in national conversations: "Corporations, like individuals, do not have monolithic views. On certain topics corporations may possess valuable expertise, leaving them the best equipped to point out errors or fallacies in speech of all sorts, including the speech of candidates and elected officials." ${ }^{.69}$ By addressing the nature of

62. Toobin, supra note 55

63. Id.

64. Id.

65. Citizens United v. Fed. Election Comm'n, 558 U.S. 310, 352 (2010).

66. 1 RodNey A. SMOlla, Law OF DeFamation $\$ 3: 14$ (2d ed. 2018).

67. Id.

68. Citizens United, 558 U.S. at 364.

69. Id. 
contemporary speech and finding that corporate political speech should receive the same First Amendment protections as other speech, the decision illustrates the impartiality with which the Court addresses speech made by different media. ${ }^{70}$ In contrast to the concerns raised by the Court's movement away from its traditional deference to the press, this impartiality appears encouraging to new media publishers in the digital age.

Similarly, in Packingham v. North Carolina, a recent case in which the Supreme Court overturned North Carolina's prohibition on sex offenders using social media, Justice Kennedy discussed social media's role as one of today's most important constitutional speech forums. He explained that

A fundamental First Amendment principle is that all persons have access to places where they can speak and listen, and then, after reflection, speak and listen once more. Today, one of the most important places to exchange views is cyberspace, particularly social media, which offers 'relatively unlimited, low-cost capacity for communication of all kinds,' to users engaged in a wide array of protected First Amendment activity on any number of diverse topics. ${ }^{71}$

Kennedy acknowledged the novelty of the digital media space, advising courts to tread carefully in this arena. He wrote,

The Internet's forces and directions are so new, so protean, and so far reaching that courts must be conscious that what they say today may be obsolete tomorrow. Here, in one of the first cases the Court has taken to address the relationship between the First Amendment and the modern Internet, the Court must exercise extreme caution before suggesting that the First Amendment provides scant protection for access to vast networks in that medium. ${ }^{72}$

In doing so, Kennedy recognized the magnitude of speech made in the digital media arena and echoed Citizens United's impartiality towards speech made in different media. Whether it be due to the volatility of today's media, a respect for cyberspace's impact, or another reason, recent First Amendment Supreme Court decisions reveal the Court's tendency to address speech protections in a media-neutral manner.

On the one hand, the Supreme Court does not seem willing to draw a firm line between the First Amendment and privacy law, and instead remains committed to considering each case on an individual basis. On the other, the Court appears medianeutral in its views and has acknowledged the significant role social media plays today. In this way, the preceding subsections shed light on the unique context in which this Note arises. Specifically, third-party funded litigation targeting negative reporting arises in a digital age characterized by the Court's tendency to blend First Amendment and privacy analysis, as well as its recognition of digital media as an important and novel-but not doctrinally distinct-space for speech. These background factors influence my consideration of possible statutory fixes to the

70. 1 Smolla on Defamation, supra note 66 , at $\S 3: 11$

71. Packingham v. North Carolina, 137 S. Ct. 1730, 1732 (2017) (quoting Reno v. Am. Civ. Liberties Union, 521 U.S. 844, 870 (1997)) (internal citation omitted).

72. Id. 
problem by underscoring the need for clear mechanisms by which digital presses can quickly and effectively counter frivolous lawsuits at a time when it can be difficult to predict how the Supreme Court will respond to growing threats to non-traditional presses.

\section{THE PROBLEM OF THIRD-PARTY LITIGATION FUNDING IN THE DIGITAL SPEECH SPACE}

Below, I discuss two recent media cases with troubling results: specifically, million-dollar costs at best and bankruptcy at worst. Bollea v. Gawker and the Mother Jones litigation forewarn the ways in which billionaires can utilize the judicial system to intentionally weaken media outlets. ${ }^{73}$ In Gawker's case, the method involved clandestine third-party litigation funding. Mother Jones concerned an announcement regarding the creation of a fund to finance litigation targeting certain media outlets, namely the liberal press.

\section{A. Billionaires Finance Litigation Targeting Negative Reporting}

\section{Gawker's Expensive Loss in the Bollea v. Gawker Invasion of Privacy Lawsuit, Secretly Financed by Peter Thiel}

Bollea v. Gawker serves as a cautionary tale of a billionaire's ability to utilize the judicial system to avenge a media outlet he or she dislikes. Terry Bollea, a wrestling star known professionally as Hulk Hogan, became famous in the 1980s and since then developed into a pop-culture sensation. ${ }^{74}$ Gawker Media, an Internet media company, comprised a network of websites dedicated to "sports, feminism and gadgets among other things" and covered celebrity, media, and entertainment gossip, as well as criticism of mainstream news outlets and investigative reporting. ${ }^{75}$ Nick Denton, Gawker's founder, stated that Gawker "published stories ahead of maintaining relationships with people, without access, favor, or discretion" and that it "cultivated an image as a publisher who always puts the story first, which can come across as being ruthless." 76 Naturally, this image produced a host of enemies. ${ }^{77}$

The Gawker case centers on the leak of a covertly recorded video capturing a 2006 sexual encounter between Hogan and Heather Clem. At the time, Heather Clem was married to Hogan's former best friend, Todd Clem, a radio personality who legally changed his name to Bubba the Love Sponge Clem. ${ }^{78}$ Bubba had hidden cameras

73. See Bollea v. Gawker Media, LLC, No. 8:12-CV-02348-T-27, 2012 WL 5509624 (M.D. Fla. Nov. 14, 2012); First Amended Complaint and Demand for Jury Trial, Bollea v. Clem, No. 12012447-CI011, 2012 WL 10731694 (Cir. Ct. Fla. Dec. 28, 2012); Vandersloot v. Found. for Nat'l Progress, No. CV2013-532 at*12, 26 (Idaho 7th Dist. Oct. 06, 2015).

74. Toobin, supra note 55.

75. Ravi Somaiya, Hulk Hogan v. Gawker: A Guide to the Trial for the Perplexed, N.Y. TIMES (Mar. 17, 2016), https://perma.cc/2SYP-5GBV.

76. Nobody SPEAK: Trials OF THE FreE PRESS (Netflix \& First Look Media 2017).

77. Publish and Be Damned: Gawker Site Shuts Down, Economist (Aug. 26, 2016), https://perma.cc/6S7S-Y2GD.

78. Gawker Media, LLC v. Bollea, 129 So.3d 1196, 1198 (2014). 
throughout his house and filmed Hogan's engagement with Clem without his permission. ${ }^{79}$ In October 2012, a month after receiving the video from an anonymous source, Gawker published a minute and forty-second excerpt of it along with a 1400word essay written by former editor, A.J. Daulerio. ${ }^{80}$ As many as four million people watched the video, making it the third most-clicked story on Gawker that year. ${ }^{81}$

Irritated by Gawker's refusal to remove the video after numerous demands, ${ }^{82}$ Hogan filed two invasion of privacy lawsuits, one in state court against Bubba and Heather Clem and the other in federal court against Gawker, Denton, and Daulerio. Hogan's Amended Complaint against Gawker asserted legal causes of action for intrusion upon seclusion, publication of private facts, violation of the Florida common law right of publicity, intentional infliction of emotional distress, and negligent infliction of emotional distress. ${ }^{83}$

After unsuccessfully seeking preliminary injunctions requiring Gawker to remove excerpts of the video, Hogan dropped the federal lawsuit. Hogan amended his state court Initial Complaint by dropping Bubba as a defendant and adding Gawker in his place. Gawker tried to remove the case to federal court but Hogan successfully filed a motion to remand it to state court. ${ }^{84}$ There the jury reached an unprecedented $\$ 140.1$ million verdict. ${ }^{85}$

Unlike Federal Judge James D. Wittemore, who found the video newsworthy and thus determined that Hogan had failed to overcome the presumption that the preliminary injunction would be an unconstitutional prior restraint under the First Amendment, the jury determined the opposite. Wittemore cited Hogan's public persona, the publicity received from his reality television show, the inclusion of extramarital affair details in his book, prior reports by other parties of the video's existence and content, and Hogan's public discussion of issues relating to his marriage and sex life to assert the video's newsworthiness. ${ }^{86}$ The jury, on the other hand, agreed with Hogan's lawyer that the distinction between Terry Bollea, the individual, and Hulk Hogan, the pop-culture icon, made the video not newsworthy for Bollea's purposes. ${ }^{87}$

To appeal the $\$ 140.1$ million verdict, the state court judge required that Gawker post a $\$ 50$ million cash bond. ${ }^{88}$ Unable to do so, Gawker corporately filed for bankruptcy and put itself up for auction. ${ }^{89}$ Eventually Gawker Media sold its

79. Toobin, supra note 55

80. Id.

81. Amy Gajda, The First Amendment Bubble: How Privacy and Paparazzi Threaten THE FREE PRESS 1 (2015).

82. Complaint and Demand for Jury Trial with Injunctive Relief Sought. Bollea v. Gawker Media, LLC, No. 8:12-cv-02348-JDW-TBM, 2012 WL 4881521 (M.D. Fla. Oct. 15, 2012).

83. Id.

84. Bollea v. Clem, 937 F. Supp. 2d 1344, 1356 (M.D. Fla. 2013).

85. Publish or Be Damned, supra note 77.

86. Bollea v. Gawker Media, LLC, No. 8:12-CV-02348-T-27, 2012 WL 5509624, at*3 (M.D. Fla. Nov. 14, 2012).

87. Toobin, supra note 55.

88. Id.

89. Alan Yuhas, Peter Thiel Justifies Suit Bankrupting Gawker, Claiming to Defend Journalism, GuARDIAN (Aug. 15, 2016, 6:59 PM), https://perma.cc/ZES8-R6C8. 
websites to Univision Communications for $\$ 135$ million and settled with Hogan by agreeing to shut down the Gawker site, pay $\$ 31$ million out of the proceeds from the sale to Univision, and relinquish the opportunity to appeal. ${ }^{90}$

Though speculation arose during the trial that a third-party funder might have been backing the case, only after did it come to light that billionaire venture capitalist Peter Thiel, a co-founder of PayPal and an early investor in Facebook, secretly financed the lawsuit. ${ }^{91}$ Thiel defended his financial support, explaining that Gawker had previously invaded his privacy and the privacy of others. ${ }^{92}$ Thiel described his support for the lawsuit, which totaled approximately $\$ 10$ million, as "one of my greater philanthropic things." 93 He also asserted that he had helped those wronged by a "singularly terrible bully." 94

Certain moves made throughout the litigation suggested that the case was about more than money and a sex tape. For example, the decision to drop the negligent infliction of emotional distress claim, which required Gawker's insurance company to pay for its defense and contribute to a settlement, drew attention. ${ }^{95}$ By dropping the claim, Hogan's legal team removed the insurance company from the equation and forced Gawker to shoulder more of the potential financial burden. Hogan also rejected multiple offers of settlement and retried a number of claims he had lost on in federal court. ${ }^{96}$ Legal experts have emphasized the unusual nature of these strategic moves. ${ }^{97}$ Without Thiel's financial backing, they may not have been possible.

Thiel also admitted that he paid for a team of lawyers to find and help "victims" of Gawker's coverage through litigation. ${ }^{98}$ In an interview, he explained that his efforts were "less about revenge and more about specific deterrence." 99 Regardless, Thiel's actions underscore the ability of billionaires to use the judicial system to target and weaken media outlets. ${ }^{100}$

90. Toobin, supra note 55.

91. Ryan Mac, This Silicon Valley Billionaire Has Been Secretly Funding Hulk Hogan's Lawsuits Against Gawker, FoRBES (May 24, 2016, 7:29 PM), https://perma.cc/DGF3-GDWR.

92. See Peter Thiel, Peter Thiel: The Online Privacy Debate Won't End With Gawker, N.Y. TIMES (Aug. 15, 2016), https://perma.cc/VC8M-FYK7. Specifically, in 2007, Gawker published an article that outed him titled "Peter Thiel Is Totally Gay, People." Owen Thomas, Peter Thiel is Totally Gay, People, GAWKER (Dec. 19, 2007, 7:05 PM), https://perma.cc/Q7NE-9PGA). Prior to Gawker's 2007 article, Valleywag, another website founded by Denton, had published negative articles about Thiel. Jeffrey Toobin, When Truth is Not Enough, NEW YORKER (Dec. 19, 2016), https://perma.cc/4RKE-786J.

93. Ryan Mac and Matt Drange, Behind Peter Thiel's Plan to Destroy Gawker, ForBes (Jun. 7, 2016, 2:51 PM), https://perma.cc/TA7D-77G4.

94. Id.

95. Andrew Ross Sorkin, Gawker Founder Suspects a Common Financier Behind Lawsuits, N.Y. TIMES (May 23, 2016), https://perma.cc/3T6M-5YNN.

96. Id.

97. Id.

98. Andrew Ross Sorkin, Peter Thiel, Tech Billionaire, Reveals Secret War with Gawker, N.Y. TIMES (May 25, 2016), https://perma.cc/7MTC-C4PE.

99. Id.

100. Though litigation funding is on the rise in the United States, with a number of large institutions offering funding, financial backing by an individual donor raises additional concerns. The Rise of $3 \mathrm{rd}$ Party Litigation Funding, LAw360 (Jan. 21, 2011), https://perma.cc/C4JF-66ZD. Roy D. Simon, a 
Bollea v. Gawker involved meritorious claims. Neither party necessarily appeared sympathetic and many people, not just the celebrities it criticized, could reasonably have been happy to see Gawker's reign come to an end. However, the precedent set by Thiel's tactics warrants concern. As Floyd Abrams explained, Thiel has legitimized the notion that "somebody not involved in a case can for the purpose of destruction of a publication, fund a litigation which may, and in this case has, had the effect of destroying it." 101 NPR Media Correspondent, David Folkenflik, identified the crucial issue that perhaps best supports the adoption of a federal antiSLAPP law. Specifically, Folkenflik asked what an independent publisher can do without the backing of a billionaire? ${ }^{102}$ Thiel effectively set the groundwork for others to follow to punish, deter, and weaken media companies. As a result, other outlets may suffer similar fates if their journalistic style and content offend individuals with pockets as deep as Thiel's.

\section{The Mother Jones's Defamation Suit and Frank VanderSloot's Fund for Future Lawsuits}

In addition to the threat of wealthy individuals financing litigation for the purposes of revenge or deterrence is the prospect of individuals creating funds to finance litigation against media outlets with which they disagree. For example, Frank VanderSloot, Idaho's wealthiest individual and founder and CEO of "wellness company" Melaleuca ${ }^{103}$ sued The Foundation for National Progress, the parent company of liberal magazine Mother Jones, and two of its employees, for defamation. ${ }^{104}$ The lawsuit concerned a 2012 Mother Jones article titled "PyramidLike Company Ponies Up \$1 Million for Mitt Romney," which Melaleuca claimed malevolently damaged VanderSloot's reputation.

At issue were Mother Jones's references to two "Community Page Ads" published by Melaleuca on June 5, 2005, and May 7, 2006, in the Idaho Falls PostRegister titled "Responsible Journalism or Misleading Propaganda?" and "Post Register Attacks the Scouts Again! When Will It Stop?"105 These "Community Page Ads" followed the publication of a six-day series of articles titled "Scout's Honor" that described pedophilia at a local Boy Scout's camp. ${ }^{106}$ The advertisements drew

professor emeritus of legal ethics at Hofstra University acknowledges how litigation financing can play an important role in leveling the playing field by helping people to litigate expensive cases against large corporations they might not otherwise have the resources to do. Sorkin, supra note 98 . But he also voices concern that "one guy is much more likely to have an agenda driven by revenge or personal dislike or wanting to prove a point." Id. While third-party funding from hedge funds and institutions boasts supporters and critics alike, clandestine funding by a single individual can be of a different nature entirely.

101. See NOBODY SPEAK, supra note 76.

102. Id.

103. Chase Peterson-Withorn, How Frank VanderSloot, Wellness Billionaire and GOP Kingmaker, Became Idaho's Richest Person, FORBES (June 21, 2017, 9:50 am), https://perma.cc/DLT5-ZMH8.

104. Complaint and Demand for Jury Trial, VanderSloot v. The Foundation for National Progress, Bonneville County case no. cv-2013-532 (filed Jan. 29, 2013).

105. Vandersloot v. Found. for Nat'l Progress, No. CV-2013-532 at *1-4 (Idaho 7th Dist. Oct. 06, 2015).

106. Id. at 1 . 
attention to the sexual orientation of the series' author and suggested his inability to be impartial on the subject matter. Mother Jones referred to these ads as support for its claim that VanderSloot is a controversial figure in Idaho politics, especially due to his stance on issues involving gays and lesbians. ${ }^{107}$

Specifically, the article stated that "[i]n 2005, he [VanderSloot] took out full-page ads in his hometown newspaper, ... the Post Register in Idaho Falls, publicly outing a reporter at the paper as gay" and "Vander Sloot's ads bashed Zuckerman, claiming that his story was an effort to smear the Boy Scouts because the organization doesn't allow gays in its membership."108 VanderSloot and Melaleuca alleged that the quoted statements, as well as a similar statement ("In 2005, Vander Sloot took out full-page newspapers ads to out a local reporter as gay") were defamatory. ${ }^{109}$ They contacted the Washington Chief Bureau of the magazine requesting retractions. ${ }^{110}$ Mother Jones temporarily removed the article from its website and then reposted it with revisions. ${ }^{11}$

After Mother Jones uploaded the revised version, VanderSloot and Melaleuca asserted that certain revised statements were defamatory. These included the following: "In 2005, he took out full-page ads in his hometown newspaper, the PostRegister in Idaho Falls, attacking the paper and one of its reporters"; "VanderSloot's ads bashed Zuckerman's reporting, while noting that he was a gay man who had admitted in a story once that 'it is very difficult for him to be objective on things he feels strongly"; and "UPDATE: The article reported previously published assertions that VanderSloot's ad in the Post-Register outed reporter Peter Zuckerman. In a letter to Mother Jones, Melaleuca general counsel Ryan Nelson maintains that the ad did not out Zuckerman because Zuckerman had discussed his homosexuality publicly while in school in Florida. But Zuckerman's boss as [sic] the paper, Dean Miller, has said that in Idaho Falls, Zuckerman 'was not 'out' to anyone but family, a few colleagues at the paper (including me), and his close friends." 112 VanderSloot and Melaleuca then sent demands for a retraction of the revised article and a related tweet. ${ }^{113}$

For a number of reasons, State court Judge Darla Williamson found for Mother Jones at summary judgment phase. Among the issues raised were the nature of the contested statements and whether actual malice had been shown. ${ }^{114}$ Considering the context and statements at issue, Williamson determined that the statements appear more like objective fact than subjective hyperbole. ${ }^{115}$ They also constitute statements of opinion that cite to their sources and provide readers with the opportunity to form their own opinions. ${ }^{116}$ Further, given the broad interpretations

107. Id. at $1-4$.

108. Id. at $2-3$.

109. Id. at 3 .

110. Id.

111. Id.

112. Id. at 3-4.

113. Id. at 4 .

114. Id. at 1 .

115. Id. at 13

116. Id. at 15 . 
provided to the contested words "out," "bash," and "attack," and the political context in which they were published, the words do not publicly disgrace or degrade VanderSloot such that they amount to defamation per se. ${ }^{117}$

Though Mother Jones ultimately prevailed on its motion for summary judgment, the magazine explained that "the take-no-prisoners legal assault from VanderSloot and Melaleuca has consumed a good part of the past two and a half years and has cost millions (yes, millions) in legal fees." 118 VanderSloot revealed his pleasure with the outcome, stating, "I feel absolutely vindicated," despite the holding in Mother Jones's favor. ${ }^{119}$ Referring to Judge Williamson's "Further Discussion," in which she revealed her concern regarding Mother Jones's style of journalism, ${ }^{120}$ VanderSloot explained, "The judge gave us much more than a jury could have ever given us. This case was never about money. Our attempt was to vindicate our good name and to point out what type of sleazy journalism that Mother Jones put out to attack conservative positions." 121 Clearly, VanderSloot's intention was not to win the case, but to punish and harm the publication. VanderSloot also announced that he would create a fund to finance similar lawsuits by "people who have been defamed by Mother Jones magazine or other liberal press because of their conservative values." 122 Given the financial strain of the litigation, as well as its time and resource costs, this announcement signifies a cause for alarm.

\section{B. The Chilling Effect of Possible Billionaire-Backed Lawsuits}

Regardless of the approach taken regarding negative reporting, namely a successful invasion of privacy suit or an unsuccessful libel suit, litigation can pose great financial strain on publishers. This section raises additional concerns that contextualize the severity of the situation new media publishers find themselves in today. Judicial protections for traditional presses cannot handle these particularized new attacks that profit from the deep pockets of their benefactors.

Not all media outlets can withstand expensive judgments. Take Alton Telegraph, for example. In 1969, James Green, a real estate developer, alleged that the Alton Telegraph libeled him in a memorandum sent to the Justice Department official leading an investigation of organized crime in Illinois. A jury awarded James Green

117. Id. at 25 .

118. Clara Jeffery and Monika Bauerlein, We Were Sued by a Billionaire Political Donor. We Won. Here's What Happened, MOTHER JONES (Oct 8. 2015), https://perma.cc/AT9R-8ZA7.

119. EastIdahoNews.com staff, VanderSloot Vindicated in Mother Jones Lawsuit, EASTIDAHONEWS.COM (Oct. 6, 2015, 8:41 PM), https://perma.cc/5XG5-TSA2.

120. In particular, Judge Williamson revealed that she was troubled by Mother Jones's "reporting styles, and indeed the general trend in political journalism." She went on to explain: "Mother Jones describes its articles as 'smart, fearless journalism,' 'ahead of the curve' and 'about reporting.' Contrary to its perception of itself, this case illustrates the non-objective bias of Mother Jones reporting and its approach in seeking out only the negative to support its position; resorting to sophomoric bullying and name-calling to lead the reader to adopt its particular agenda." VanderSloot, No. CV-2013-532 at *12, *26 (Idaho 7th Dist. Oct. 06, 2015).

121. EastIdahoNews.com staff, supra note 119.

122. EastIdahoNews.com staff, VanderSloot: "I'm establishing a fund to defend conservatives defamed by liberal press, " EASTIDAHONEWS.COM (Oct. 6, 2015, 8:40 PM), https://perma.cc/ZL2F-9H9V. 
with $\$ 6.7$ million in compensatory damages and $\$ 2.5$ million in punitive damages, forcing the Alton Telegraph to file for bankruptcy to prevent selling its assets. Though the newspaper ultimately reached a settlement of $\$ 1.4$ million and stayed in business, its near destruction reveals how harmful a successful libel action can be to small media outlets. ${ }^{123}$

However, the threat of successful libel action is not necessarily what influences publications. Rather, it is the threat of any litigation. The process by which parties reach a judgment in a libel action is large and expensive. ${ }^{124}$ This economic reality discourages some in the media from taking on stories or certain approaches to stories that they know might lead to litigation, even if they believe they can win. ${ }^{125}$ In fact, there may be a direct economic correlation between the costs of defense in media cases and the exercise of free speech rights by media outlets. ${ }^{126}$ The potential chilling effect has been discussed long before the Gawker and Mother Jones cases began. ${ }^{127}$ In 1983, Rodney A. Smolla asserted the rejuvenation of libel law in America, and in 1995 David Boies spoke about the chilling effects of libel defamation costs. ${ }^{128}$

Yet the realized threat of billionaire litigation funders constitutes an even greater danger to media outlets in the digital age. These outlets utilize different tones, incorporate new media, and put out accessible content at a rapid rate. They also do not necessarily enjoy the deep pockets of more traditional presses. Moreover, Boies explains that non-economic motives at play in defamation litigation prove particularly problematic for defendants since plaintiffs are less motivated by a quantifiable economic loss and less constrained by the economic costs of litigation than most potential plaintiffs. ${ }^{129}$ Like in Bollea v. Gawker, this can lead to strategic moves that require media outlets to shoulder great burdens and expend substantial finances and resources through prolonged litigation. This reality can threaten the editorial independence media outlets enjoy. ${ }^{130}$

For example, it appears that the American Bar Association (A.B.A.) declined to publish its report on Donald Trump's litigation history for fear of being sued. ${ }^{131}$ Commissioned by a committee of media lawyers at the A.B.A., the report analyzed seven free speech related lawsuits and determined that Trump was a "libel bully" who filed meritless lawsuits and never won in court. Originally titled "Donald J. Trump is a Libel Bully but Also a Libel Loser," the A.B.A. proposed the alternative title: "Presidential Election Demonstrates Need for Anti-Slapp Laws." An A.B.A.

123. See Steven D. Zansberg, Recent High-Profile Cases Highlight the Need for Greater Procedural Protections for Freedom of the Press, CoMms LAws, Fall 2017, https://perma.cc/J5QB-V2FE (providing numerous examples of federal and state courts acknowledging, decades ago, the toll litigation can take on media outlets).

124. Boies, supra note 53, at 1298.

125. Id.

126. 1 Smolla on Defamation, supra note 66, at § 13:4.

127. Zansberg, supra note 123,Error! Bookmark not defined. at 8-9.

128. Rodney A. Smolla, Let the Author Beware: The Rejuvenation of the American Law of Libel, 132 U. PA. L. REV. 1 (1983); Boies, supra note 53.

129. Boies, supra note 53,53 at 1298-99.

130. 1 Smolla on Defamation, supra note 66 , at $\S 13: 4$.

131. Adam Liptak, Fearing Trump, Bar Association Stifles Report Calling Him a "Libel Bully," N.Y. TIMES (Oct. 24, 2016), https://perma.cc/QN3S-FRXC. 
spokeswoman explained that they had simply made routine objections and edits, while committee members that wrote the report revealed their distress at the A.B.A.'s revisions. ${ }^{132}$

Moreover, Jim DeRogatis, a Chicago rock critic, and the author of a story detailing how R\&B singer R. Kelly psychologically and sexually controlled young women as if in a cult, had considerable difficulty finding an outlet to publish his piece. When he tried to publish his story, multiple media organizations seemed interested initially but backed out at the last minute. ${ }^{133}$ DeRogatis explained that Gawker often came up in conversation when the organizations conveyed their hesitation. ${ }^{134}$ Though Buzzfeed ultimately published the story after ensuring its accuracy, the fact that media organizations feared taking the risk to publish a groundbreaking story that had been reported on for months underscores potential litigation's chilling effect. ${ }^{135}$

\section{A FEDERAL ANTI-SLAPP LAW AS A POSSIBLE SOLUTION}

In light of possible billionaire-financed litigation targeting media outlets, this Note proposes the adoption of a federal anti-SLAPP law. ${ }^{136}$ Supporters of a federal anti-SLAPP law span a variety of industries yet share a common desire to protect defendants exercising their free speech and petition rights from the chilling effect of strategic lawsuits against public participation (SLAPPs) aimed solely at intimidating and silencing defendants. The goal of SLAPPs is not to win on the merits, but to discourage defendants from enjoying their First Amendment rights through the threat of devastatingly expensive litigation. ${ }^{137}$ Anti-SLAPP laws combat SLAPPs by offering defendants important procedural protections. On the most basic level, Thiel's and VanderSloot's actions can be characterized as SLAPPs. Their clear intentions to deter and to exact revenge on specific media outlets through expensive, targeted litigation mirror the intentions of SLAPP plaintiffs, generally. Given the precedent they set by inflicting harm on media defendants through financing litigation or allegedly creating funds to do so, a federal anti-SLAPP law emerges as a promising solution to protect media outlets at risk for similar actions in the future.

132. Id.

133. Id.

134. Id.

135. Id.

136. For a different answer, see Lili Levi, The Weaponized Lawsuit Against the Media: Litigation Funding as a New Threat to Journalism, 66 AM. U. L. REV. 761 (2017). Levi's Article discusses thirdparty litigation funding cases targeting the media, including Bollea v. Gawker and the Mother Jones case, and advocates for a four-part solution. In particular, Levi proposes "(1) judicial discretion to order disclosure of third-party funding in discovery; (2) waiver or reduction of appeal bonds in third-partyfunded media cases where such bonds would effectively make verdicts against the media unappealable; (3) development of counter-funding strategies and support of third-party-funding watchdogs; and (4) consideration of a litigation misuse claim against third-party funders in cases where their support is designed to shutter press outlets." Id. at 761-62.

137. What is a SLAPP?, PUB. PARTICIPATION PROJECT, https://perma.cc/83XZ-SGYQ (last visited Nov. 15, 2018). 


\section{A. Anti-SLAPP Law Origins}

In response to a rise in lawsuits seeking large civil damages from environmental protection advocates and organizations, Penelope Canan and George W. Pring began studying litigation arising from "citizen contact with a government official, agency, or the electorate on a substantive issue of public significance."138 In essence, they analyzed a trend involving individuals sued for activities long considered to be acceptable public participation. Such activities included, among other things, writing editorials, speaking at town meetings, taking part in referendums, reporting health violations to officials, and engaging in peaceful demonstrations. ${ }^{139}$ Canan and Pring coined the phrase "strategic lawsuit against public participation" abbreviated as "SLAPP," to describe the phenomenon. ${ }^{140}$

Canan and Pring reached a number of conclusions regarding SLAPP lawsuits. Specifically, they found that four features characterize SLAPPs. These include: a civil claim for money damages, defendants who are nongovernmental individuals and organizations, claims based on advocacy before a government branch official or the electorate, and advocacy dealing with a substantive issue of public or societal significance. ${ }^{141}$ SLAPP lawsuits share not only a lack of merit, but an intention to silence and intimidate critics by subjecting them to litigation's time and money requirements. SLAPPs chill public participation by effectively conveying the message "shut up or be sued." 142 To combat SLAPP lawsuits, states began enacting anti-SLAPP laws that provide SLAPP defendants with certain protections.

\section{B. CONTEMPorary ANTi-SLAPP LAW CONTEXt}

Since the state of Washington enacted the first anti-SLAPP law in 1989, thirtyone states, along with the District of Columbia and Guam, have passed anti-SLAPP laws. ${ }^{143}$ These laws differ from state to state, but they typically include a few similar features. Anti-SLAPP laws usually provide defendants with an expedited process to dismiss the case, with little or no discovery, and they afford fee-shifting measures. ${ }^{144}$

138. Penelope Canan \& George W. Pring, Studying Strategic Lawsuits Against Public Participation: Mixing Quantitative and Qualitative Approaches, 22 LAW \& SOC'Y REV. 385, 386-87 (1988).

139. Jeffrey A. Benson et al., Strategic Lawsuits Against Public Participation (SLAPPs): An Overview, C750 ALI-ABA 837, 839 (Aug 19, 1992); Penelope Canan \& George W. Pring, "Strategic Lawsuits Against Public Participation" ("SLAPPs"): An Introduction for Bench, Bar and Bystanders, 12 BRIDGEPORT L. REV. 937, 938 (1992); Canan \& Pring, supra note 138,138 at 387-88.

140. Canan \& Pring, supra note 138,138 at 387.

141. Id.

142. Benson et al., supra note 139,139 at 940; Canan \& Pring, supra note 138, at 386-90.

143. Robert T. Sherwin, Ambiguity in Anti-SLAPP Law and Frivolous Litigation, 40 ColuM. J.L. \& ARTs 431, 433 (2017); State Anti-SLAPP Laws, PUB. PARTICIPATION PROJeCT, https://perma.cc/4YU99737 (last visited Nov. 15, 2018) (describing the features of anti-SLAPP laws in Arizona, Arkansas, California, Connecticut, Delaware, District of Columbia, Florida, Georgia, Hawaii, Illinois, Indiana, Kansas, Louisiana, Maine, Maryland, Massachusetts, Minnesota, Missouri, Nebraska, Nevada, New Mexico, New York, Oklahoma, Oregon, Pennsylvania, Rhode Island, Tennessee, Texas, Utah, Vermont, Virginia, and Washington).

144. Sherwin, supra note 143, at 433; Cliff Zatz, Joe Meadows, \& Laura Aradi, What's Next For Federal Anti-SLAPP Legislation, LAW360 (Apr. 19, 2017), https://perma.cc/L9QN-PNUU. 
A comparison of a few state anti-SLAPP laws reveals the extent to which the scope of activity they cover can vary. For example, New York's anti-SLAPP law offers narrow protection. It provides a special motion to strike a cause of action against a person arising from speech that comments on, rules on, or contests an application or permission by the government. ${ }^{145}$ This law covers individuals who have applied for or obtained a permit, zoning change, lease, license, or other entitlement for use or permission to act. ${ }^{146}$

California's anti-SLAPP law, on the other hand, offers expansive protection. Its law provides a special motion to strike a cause of action against a person "arising from any act of that person in furtherance of the person's right of petition or free speech under the United States Constitution or the California Constitution in connection with a public issue" unless the court determines that there is a probability that the plaintiff will prevail on his or her claim. ${ }^{147}$ The statute covers written or oral statements made before a government body or official proceeding, statements made in connection with an issue under consideration by a government body, and written or oral statements made in public on an issue of public interest. It also covers any other conduct concerning petition or free speech in connection with an issue of public interest. ${ }^{148}$ As follows, the scope of activity covered can vary greatly from state to state.

While Canan and Pring's initial conception of SLAPPs referred to threats to the right to petition, the term's connotation has since expanded to include lawsuits intended to intimidate and silence critics exercising First Amendment rights to speak and publish as well. ${ }^{149}$ For example, the increasing popularity of online reviews has fueled many contemporary SLAPP lawsuits. ${ }^{150}$ In response, Yelp established a political office in Washington, D.C. committed to forming a coalition to lobby for a federal anti-SLAPP law. ${ }^{151}$

Additionally, federal courts disagree on whether state anti-SLAPP laws apply in federal court for diversity actions. ${ }^{152}$ A variety of scholarship exists both for and against application of these state laws at the federal level. ${ }^{153}$ Some argue that state

145. N.Y. CiV. RightS LAW § 70-a \& 76-a (McKinney 2008); N.Y. C.P.L.R. 3211 (McKinney 2006); New York, PUBLIC PARTICIPATION PROJECT, https://perma.cc/LKZ6-5EXY.

146. N.Y. CIV. RigHTS LAW § 76-a (McKinney 2008).

147. CAL. Civ. Proc. CODE $\$ 425.16$ (b)(1) (West 2016) (emphasis added).

148. CAL. Civ. Proc. Code $\S 425.16$ (e) (West 2016).

149. Zatz, Meadows, \& Aradi, supra note 144.

150. Id.

151. Sherwin, supra note 143, at 464 (citing Josh Harkinson, Yelp Is Pushing a Law to Shield Its Reviewers from Defamation Suits, MOTHER JONES (July 20, 2015), https://perma.cc/3YN8-GGKR).

152. Examining H.R. 2304, The "SPEAK FREE Act": Hearing Before the Subcomm. on the Constitution and Civil Justice of the H. Comm. on the Judiciary, 114th Cong. 67 (2016) [hereinafter Hearing] (statement of Laura Lee Prather, Partner, Haynes and Boone LLP, testifying on behalf of the Public Participation Project).

153. See Colin Quinlan, Erie and the First Amendment: State Anti-SLAPP Laws in Federal Court After Shady Grove, 114 Colum. L. Rev. 367 (2014); Katelyn E. Saner, Getting SLAPP-ed in Federal Court: Applying State Anti-SLAPP Motions to Dismiss in Federal Court After Shady Grove, 63 DUKE L.J. 781 (2013); Yando Peralta, State Anti-SLAPPs and Erie: Murky, But Not Chilling, 26 FordHAM InTELL. ProP. MEDIA \& ENT. L.J. 769; Caleb P. Lund, It's Time to SLAPP Back: Why California's Anti-SLAPP Statute Should Not Apply in Federal Court, 44 Sw. L. REV. 97 (2014). 
anti-SLAPPs directly conflict with Federal Rules of Civil Procedure 12 and 56, and thus should not apply in federal court. ${ }^{154}$ Others believe that applying state antiSLAPP laws in federal court aligns with Erie's twin aims by "removing the incentive for filers to shop for a federal forum in order to evade anti-SLAPP protections, and by preventing the inequitable treatment of targets' legitimate petitioning activity." 155 A federal anti-SLAPP would eliminate strategic forum-shopping by SLAPP plaintiffs and establish uniformity by providing media outlets with an important weapon regardless of where SLAPP suits are filed.

\section{What Should a Federal ANTI-SLAPP LAW LoOK Like?}

\section{The SPEAK FREE Act of 2015}

In May 2015, a bipartisan coalition in the House of Representatives introduced the "Securing Participation, Engagement, and Knowledge Freedom by Reducing Egregious Efforts Act of 2015," also known as the SPEAK FREE Act, in an effort to enact a federal anti-SLAPP law. ${ }^{156}$ With more than thirty co-sponsors, it was the third anti-SLAPP bill introduced. ${ }^{157}$ The SPEAK FREE Act provides a solid blueprint for an effective federal anti-SLAPP law solution that I will build upon below.

The SPEAK FREE Act effectively provides a mechanism for federal courts to quickly dispose of meritless lawsuits intended to silence individuals for exercising their First Amendment rights. The Act received support from fifty organizations that spanned various industries including The Electronic Frontier Foundation, Glassdoor, Media Law Resource Center, Public Participation Project, SnapChat, and Yelp. ${ }^{158}$ In addition, over 100 organizations and businesses support federal anti-SLAPP legislation in general. ${ }^{159}$

The SPEAK FREE Act defines a "SLAPP suit" as a "claim that arises from an oral or written statement or other expression, or conduct in furtherance of such expression, by the person against whom the claim is asserted that was made in connection with an official proceeding or about a matter of public concern." 160 This broad definition covers a range of activity and essentially protects any speech or conduct connected to a matter of public concern. The Act delivers a number of features including quick dismissal of SLAPP suits, removal to district court, a stay of discovery, and an award of attorney's fees. ${ }^{161}$

Specifically, the Act provides a special motion to dismiss if the filing party "makes a prima facie showing that the claim at issue arises from an oral or written statement or other expression by the defendant that was made in connection with an

154. Peralta, supra note 153 , at 771 .

155. Quinlan, supra note 153, at 405.

156. Speak Free Act of 2015, Public Participation Project, https://perma.cc/GYZ6-3ZSZ.

157. Id. See also Zatz, Meadows, \& Aradi, supra note 144.

158. Coalition of Supporters, PUBLIC PARTICIPATION PROJECT, https://perma.cc/JAJ4-8SMT.

159. Id.

160. H.R. 2304, 114th Cong. § 4201 (2015).

161. See generally H.R. 2304, 114th Cong. (2015). 
official proceeding or about a matter of public concern" unless the responding party shows that the claim is likely to succeed on the merits. ${ }^{162}$ The Act provides three exceptions. Specifically, enforcement actions, commercial speech, and public interest are exempt from the special motion option. ${ }^{163}$

Motions to dismiss must be filed within forty-five days if the claim is filed initially in federal court, or within thirty days after the date of removal if the claim is filed initially in state court and removed. ${ }^{164}$ Hearings must be held no later than thirty days after a special motion to dismiss is served, and no less than ninety days after the special motion to dismiss is served if the hearing must be postponed. ${ }^{165}$ These requirements guarantee a speedy resolution of the anti-SLAPP dispute.

Furthermore, the Act provides for a stay of discovery unless there is a showing of good cause for specific discovery. ${ }^{166}$ Aggrieved parties may make an intermediate interlocutory appeal and cases can be removed from state to federal district court. ${ }^{167}$ The Act also provides attorneys' fees to the party that files and prevails on a motion to dismiss or a motion to quash based on personally identifying information sought in connection with a claim. ${ }^{168}$ While the SPEAK FREE Act ultimately was not signed into law, it provides the building blocks for an effective federal anti-SLAPP law.

\section{Important Features to Include in Future Bills}

This section builds upon the blueprint established by the SPEAK FREE Act of 2015. It begins with an analysis of the concerns raised during and after the June 22, 2016 hearing on the Act and culminates in a proposal for a viable federal anti-SLAPP solution that includes specific features.

\section{a. A Broad SLAPP Definition with Specific Exceptions}

A federal anti-SLAPP bill that includes a broad SLAPP definition, as well as specific exceptions, is necessary for striking the proper balance between protecting opposing parties' First Amendment rights and their access to the courts. Crafting a suitable definition inevitably requires walking a fine line. By defending one person's freedom of speech, an anti-SLAPP law can run the risk of intruding on the opposing person's "right to petition." 169 Indeed, an overly broad SLAPP definition can undermine anti-SLAPP's goal of preventing retaliatory lawsuits against individuals exercising their First Amendment rights.

162. H.R. 2304, 114th Cong. § 4202(a) (2015).

163. H.R. 2304, 114th Cong. § 4202(b) (2015).

164. H.R. 2304, 114th Cong. § 4202(d) (2015).

165. H.R. 2304, 114th Cong. \& 4202(e) (2015).

166. H.R. 2304, 114th Cong. § 4203 (2015).

167. H.R. 2304, 114th Cong. $\S \S 4204,4206$ (2015).

168. H.R. 2304, 114th Cong. § 4207(a) (2015).

169. London Wright-Pegs, Comment, The Media SLAPP Back: An Analysis of California's AntiSLAPP Statute and the Media Defendant, 16 UCLA ENT. L. REV. 323, 330 (2009). 
SPEAK FREE Act critics argued that its broad scope and narrow exceptions might undermine legitimate lawsuits including those pursuing cases to "enforce civil rights, stop employment discrimination, blow the whistle on fraud, ensure fair competition, and protect copyright." 170 Professor Reinert of Cardozo Law School argued that the bill's SLAPP definition might cover speech and conduct not protected by the First Amendment and threaten important cases not traditionally considered SLAPP suits, such as those brought by individual plaintiffs against powerful government or private interests. ${ }^{171}$ Representative John Conyers, Jr. went so far as to describe the bill as "yet another measure intended to severely impede the ability of those with legitimate claims to obtain justice in court." 172

Critics also voiced concerns about the bill's "matter of public concern" definition. In particular, the bill provides that a defendant in any lawsuit that "arises from" expression or an act in furtherance of such expression "in connection with an official proceeding or about a matter of public concern" can file a "special motion to dismiss the lawsuit." 173 The bill defines "matter of public concern" generously, including under its umbrella any issue related to "health or safety," "environmental, economic, or community well-being," "the government," "a public official or public figure;" or "a good, product, or service in the marketplace." 174 Critics specifically disapproved of the definition's over-expansiveness, arguing that it could potentially apply to a sexual harassment claim under Title VII of the Civil Rights Act of $1964 .{ }^{175}$

An improved definition of SLAPP lawsuits with a narrower definition of "matter of public concern" and more specific exemptions should be included in future bills to assuage critics' fears. Expanding and tailoring the public interest exception to the community at risk is one possible improvement. ${ }^{176}$ Exempting certain types of lawsuits like employment discrimination, securities fraud, antitrust, whistleblower, and products liability cases can prevent the application of special motions to dismiss in unintended cases. ${ }^{177}$

While a definition that is too broad can pose problems, a broader definition, like California's, as opposed to New York's, is essential to cover the activity at issue in the media context. For example, the federal anti-SLAPP law could learn from California's experience. California enacted $\S 425.17$ to address abuse of its antiSLAPP law. Section 425.17 prohibits anti-SLAPP motions in response to public interest litigation when certain conditions are met. It also prohibits anti-SLAPP motions in actions against a business arising from commercial statements or business

170. Hearing, supra note 152, at 23 (statement of Rep. Cohen, Ranking Member, H. Subcommittee on the Constitution and Civil Justice).

171. Id. at 53 (statement of Alexander A. Reinert, Professor of Law, Benjamin N. Cardozo School of Law).

172. Id. at 26 (statement of Rep. Conyers, Jr., Ranking Member, H. Comm. on the Judiciary).

173. H.R. 2304, 114th Cong. $\S \S 4201,4202$.

174. H.R. 2304, 114th Cong. § 4208(1).

175. Hearing, supra note 152, at 29 (statement of Rep. Conyers, Jr., Ranking Member, H. Comm. on the Judiciary).

176. Id. at 55 (statement of Alexander A. Reinert, Professor of Law, Benjamin N. Cardozo School of Law).

177. Zatz, Meadows, \& Aradi, supra note 144144. 
conduct. ${ }^{178}$ In this way, California's statute provides SLAPP defendants protections for a wide array of First Amendment activities while striving to prevent abuse.

It has been suggested that anti-SLAPP laws should define protected activity in such a way that explicitly limits potential media abuse, such as "allowing protection for only true, lawful and legitimately achieved information" to fulfill the purpose of protecting "citizen participation in government." 179 Yet, because the "actual malice" standard does not require that information published be true, this definition would interfere too much with the protected activity of media outlets. Tailoring the "matter of public concern" definition and including exemptions to cover unintended cases that can inadvertently fall within the federal anti-SLAPP realm would improve the law's definition while balancing the competing interests of opposing parties.

\section{b. A Pleading Standard that Avoids Both Vagueness Concerns and a 7th Amendment Conflict}

A standard for dismissal that gets rid of clearly frivolous lawsuits without too much of a burden on the plaintiff that filed the original lawsuit is crucial in the digital media context. Of course, a standard that places a higher burden on plaintiffs than does the summary judgment standard raises concerns. To ensure the bill's passage, lawmakers should adopt a standard to avoid dismissal that is no higher than the summary judgment standard. ${ }^{180}$ Alternatively, lawmakers can implement the standard provided by California's anti-SLAPP law.

The SPEAK FREE Act's requirement that a court grant a special motion to dismiss the SLAPP claim unless the plaintiff shows that she is "likely to succeed on the merits" of her claim upset lawmakers who asserted that it was a burden too difficult to meet without discovery, even for meritorious claims. ${ }^{181}$ Lawmakers have emphasized that such a burden is higher than that required in a regular motion to dismiss or motion for summary judgment under Federal Rules of Civil Procedure 12 and 56. ${ }^{182}$ Moreover, the likelihood of success standard may be unconstitutional in comparison to the summary judgment standard. Specifically, the "well-worn standard after summary judgment" is that a plaintiff, after discovery, must only show that a reasonable jury could find in her favor. ${ }^{183}$ The SPEAK FREE Act's standard, on the other hand, envisions courts determining the likelihood of success, a higher burden of proof, without access to an evidentiary record. This discrepancy proves problematic when filtering claims in federal court before discovery. ${ }^{184}$

Furthermore, a special motion to dismiss with a likelihood of success burden of proof may be inherently vague and require the judge to commandeer the jury's role

\footnotetext{
178. CAL. Civ. Proc. CODE $\S 425.17$ (West 2016).

179. See Wright-Pegs, supra note 169 , at 341.

180. Zatz, Meadows, \& Aradi, supra note 144.

181. Hearing, supra note 152, at 27 (statement of Rep. Conyers, Jr., Ranking Member, H. Comm. on the Judiciary).

182. Id.

183. Id. at 47-48 (statement of Alexander A. Reinert, Professor of Law, Benjamin N. Cardozo School of Law).

184. Id.
} 
in making its determination. ${ }^{185}$ Specifically, this standard seems to require judges to engage in tasks traditionally assigned to the jury, like making factual determinations, weighing evidence, and assessing the evidence's credibility. As such, it risks violating the Seventh Amendment. ${ }^{186}$ If, on the other hand, the standard merely requires judges to determine whether enough evidence has been offered to satisfy each element of the claim or whether any reasonable jury could find in favor of the petitioner, then it passes muster. ${ }^{187} \mathrm{~A}$ future bill must provide greater clarity regarding what its standard requires. Moreover, to withstand the aforementioned criticisms, a future bill should set a standard to avoid dismissal that is no higher than the summary judgment standard, or implement California's requirement that a plaintiff need only show that there is a "probability that the plaintiff will prevail." 188

\section{c. A Removal Provision that Includes Explicit Conditions}

Because state anti-SLAPP laws vary greatly, SLAPP plaintiffs can make strategic forum choices and capitalize on legal vulnerabilities, including disparate or nonexistent anti-SLAPP laws throughout the country. ${ }^{189}$ This was the case with Mother Jones since Idaho had no state anti-SLAPP law. A removal provision is necessary to establish uniformity and combat the strategic efforts of SLAPP plaintiffs. Further, digital media's reach, which by nature crosses state lines, underscores the importance of a uniformly applicable removal provision that eliminates strategic forumshopping.

The SPEAK FREE Act's removal provision upset critics due to its federalism implications. Critics explained that a minority of states had chosen not to enact antiSLAPP laws ${ }^{190}$ and they emphasized that this choice represents the experimentation that federalism intends to promote. ${ }^{191}$ Including a removal provision may therefore encroach on the fundamental federal-state balance. ${ }^{192}$ Further, a removal provision can motivate reverse forum-shopping for targets sued in states without anti-SLAPP statutes who can now gain access to federal court. ${ }^{193}$ Allowing the removal of purely

185. Eric Simpson, Slapp-ing Down the Right to a Jury Trial: Anti-Strategic Lawsuits Against Public Participation and the Seventh Amendment, 48 U. TOL. L. REV. 169, 181-82 (2016).

186. Id.

187. Id. at $185-86$.

188. CAL. CIV. Proc. CODE $\S 425.15(\mathrm{~b})(1)$.

189. Nicole K. Chipi, Note, Eat Your Vitamins and Say Your Prayers: Bollea v. Gawker, Revenge Litigation Funding, and the Fate of the Fourth Estate, 72 U. MIAMI L. REV. 269, 291-92 (2017). Chipi includes a footnote citing Order at 2, Dean v. NBC Universal, No. 2011 CA-006055-B (D.C. Super. Ct. June 25,2012 ) as an example of a party removing a case to federal court to avoid application of a state's anti-SLAPP law and its associated procedural measures. $I d$. at 292 n.153.

190. Aaron Smith, SLAPP Fight, 68 ALA. L. REV. 303, 332 (2016).

191. Hearing, supra note 152, at 59 (statement of Alexander A. Reinert, Professor of Law, Benjamin N. Cardozo School of Law).

192. Smith, supra note 190 , at 332 .

193. Id. 
state-law claims to federal court in the absence of diversity jurisdiction or a federal question may also exceed the bounds of Article III of the Constitution. ${ }^{194}$

On the other hand, supporters of the bill argued for the constitutionality of its removal provision. In his Prepared Statement, Jeremy B. Rosen, a partner at Horvitz \& Levy LLP, explained that Congress has the authority to decide the cases federal courts can consider, as long as Congress remains within Article III bounds. Rosen clarified that according to Article III, "[t]he judicial power shall extend to all Cases, in Law and equity, arising under this Constitution...."195 Because Article III's "arising under" jurisdiction "may extend to all cases in which a federal question is "an ingredient' of the action," 196 as long as the claims covered by the removal provision incorporate a federal question, Congress can properly grant courts the jurisdiction to hear these claims. The SPEAK FREE Act's removal provision $\S$ 4206(a) covers claims under $\S 4201 .{ }^{197}$ Because $\S 4201$ 's claims arise in whole or in part from free speech and petitioning activities protected by the First Amendment, the removal provision properly covers claims that incorporate a federal question. ${ }^{198}$

Because the provision allows removal when the application of First Amendment rights and defenses will be raised in the action, Bruce D. Brown of the Reporters Committee for Freedom of the Press, argued that the provision's plain language is proper because it implies that a defendant must show proper reasons for removal in her petition for removal if the complaint does not clearly declare them. ${ }^{199}$ Brown acknowledged that the provision's text does not explicitly state this reality so he suggested a modification that can quell critics' concerns. Specifically, he explained that the provision could be revised to state the following: "The grounds for removal provided in this section need not appear on the face of the complaint but may be shown in the petition for removal by asserting that the civil action may be defeated by a defense arising under the First Amendment." ${ }^{200}$ According to Brown, this revision "is not necessary to preserve the removal provision's constitutional validity, [but] it may further illuminate the intent of Congress." 201

For these reasons, a future removal provision should explicitly state a number of things. Specifically, it should clearly restrict removal of cases to those that involve federal defenses, like the First Amendment, so that removed cases unambiguously raise a federal question for jurisdictional purposes. ${ }^{202}$ And a removal provision should include language addressing the First Amendment to alleviate critics'

194. Hearing, supra note 152, at 30 (statement of Rep. Conyers, Jr., Ranking Member, H. Comm. on the Judiciary).

195. U.S. Const. art. III, § 2, cl. 1.

196. Hearing, supra note 152, at 95 (statement of Jeremy B. Rosen, Partner Horvitz \& Levy LLP (citing Merrell Dow Pharms., Inc. v. Thompson, 478 U.S. 804, 807 (1986))).

197. Id. at 96 (statement of Jeremy B. Rosen, Partner Horvitz \& Levy LLP).

198. Id.

199. Hearing, supra note 152, at 114-15 (statement of Bruce D. Brown, Executive Director of the Reporters Committee for Freedom of the Press).

200. Hearing, supra note 152, at 115 (statement of Bruce D. Brown, Executive Director of the Reporters Committee for Freedom of the Press).

201. Id.

202. Zatz, Meadows, \& Aradi, supra note 144. 
concerns regarding the potential for removing purely state law claims in the absence of diversity jurisdiction. Limiting removal to claims founded on federal law, diversity clams, or claims in which a First Amendment defense is raised, prevents jurisdictional deficiencies.

\section{d. An Enumerated Commerce Clause Hook}

An enumerated Commerce Clause hook would unambiguously verify federal antiSLAPP law drafters' authority to enact such a law. ${ }^{203}$ In particular, the Commerce Clause grants Congress the authority to regulate the channels and instrumentalities of interstate commerce, as well as economic activities that "substantially impact" interstate commerce. ${ }^{204}$ Traditional and new media's activities and reach support the argument that lawsuits targeting these media defendants substantially affect the interstate commerce of communications. A similar argument can also be made regarding the activities and reach of online review sites. Hard-copy news circulation crosses state lines and access to digital news and online reviews appears ubiquitous. As follows, lawsuits targeting media companies and online reviewers implicate interstate commerce and threaten national media and online review markets. Thus, these suits encompass some of the "activities" that the Commerce Clause authorizes Congress to regulate.

It is more difficult to argue that lawsuits targeting individual SLAPP defendants petitioning local government substantially threaten interstate commerce. However, under Gonzales v. Raich, the Supreme Court determined that Congress has the authority to regulate an entire class of activities if it "decides that the 'total incidence' of a practice poses a threat to a national market." ${ }^{205}$ If one can argue that lawsuits targeting these petitioners in the aggregate affect interstate commerce and thereby threaten some national market, then a Commerce Clause hook could sweep in not only the media lawsuits central to this Note, but also lawsuits involving other forms of free speech and petitioning activities.

At the least, a federal anti-SLAPP law should include a hook that explains Congress's Commerce Clause power to regulate activities that substantially affect interstate commerce. The hook should specifically detail the interstate commerce of communications that is relevant in this context and illuminate why meritless lawsuits targeting media defendants constitute a type of activity that Congress can regulate.

\section{CONCLUSION}

A strong federal anti-SLAPP law would provide vital protection for media defendants at risk for future actions similar to Thiel's and VanderSloot's. An effective federal anti-SLAPP law would build on the SPEAK FREE Act of 2015's

203. U.S. Const. art. I, $\S 8$, cl. 3 ("The Congress shall have Power... To regulate Commerce with foreign Nations, and among the several States, and with the Indian Tribes.").

204. Id. See also Hearing, supra note 152, at 112 (statement of Bruce D. Brown, Executive Director of the Reporters Committee for Freedom of the Press) (internal citations omitted).

205. Id. (citing Gonzales v. Raich, 545 U.S. 1, 17 (2005)). 
blueprint and include the following features: (1) a broad SLAPP definition with specific exceptions, (2) a pleading standard that avoids both vagueness concerns and a 7th Amendment conflict, (3) a removal provision that includes explicit conditions, and (4) an enumerated commerce clause hook. A federal anti-SLAPP law with these features would offer an avenue by which media defendants hit with baseless SLAPP lawsuits can avoid the high costs of litigation. Such a law would provide uniformity nationwide, eliminate strategic forum-shopping by SLAPP plaintiffs, and help media outlets without the deep pockets of their older, more traditional counterparts. Further, it would level the playing field between opposing parties, a possibility especially important in the digital age where many media outlets, print and post-print alike, struggle financially. A federal anti-SLAPP law would not throw out all lawsuits against the media. However, it could prevent extensive time and resource loss by disposing of meritless lawsuits modeled on and inspired by Thiel's and VanderSloot's efforts. 